\title{
Chemotaxonomical characterisation of males of Bombus lucorum (Hymenoptera: Apidae) collected in the Czech Republic
}

\author{
KLÁRA URBANOVÁ, IrENA VALTEROVÁ, OLdŘICH HOVORKA and JiŘí KINDL \\ Institute of Organic Chemistry and Biochemistry, Academy of Sciences of the Czech Republic, Flemingovo náměstí 2 , \\ 16610 Praha 6, Czech Republic
}

Key words. Hymenoptera, Apidae, Bombus lucorum, bumblebees, marking pheromone, labial gland secretion, chemosystematics, ethyl (Z)-9-tetradecenoate

\begin{abstract}
Labial gland secretions of 26 males of the bumblebee Bombus lucorum (L.), collected in the Czech Republic, were analysed. The secretions consisted of 60 compounds; ethyl (Z)-9-tetradecenoate was the main component (average 53\%). Although the males varied in colour, their labial gland secretions were similar in composition, which indicated they belonged to one species. Chemically the B. lucorum occurring in the Czech Republic correspond to the earlier described "blonde form" of this species.
\end{abstract}

\section{INTRODUCTION}

The species of bumblebees (Bombus Latreille, 1802) belonging to the subgenus Bombus s.str. are often difficult to determine. Colouration is very variable and other morphological differences are indistinct. Individuals of the "lucorum species group" are especially difficult to distinguish morphologically (Krüger, 1954). In West and Central Europe this group consists of Bombus (s.str.) lucorum (Linnaeus, 1761) and two other closely related species - $B$. (s.str.) magnus Vogt, 1911 and $B$. (s.str.) cryptarum (Fabricius, 1775).

Bombus lucorum in the broadest sense (the taxonomy and nomenclature is very confused - see Williams, 1991, p. 81-85) is a widely distributed bumblebee species, which occurs throughout the Palaearctic. It is one of the commonest bumblebee species in Central and Northern Europe (Rasmont, 1984). The males are very variable in colour throughout their distribution. Due to their morphological similarity $B$. cryptarum (Rasmont, 1984) and B. magnus (Løken, 1973) have either been regarded as distinct species or have been synonymised with $B$. lucorum, sometimes even with B. terrestris (Warncke, 1981, 1986). This has led several authors to use characteristics other than morphological and morphometrical ones to separate these taxa. Species can be distinguished using enzyme electrophoresis (Scholl et al., 1983, 1992) or the chemical composition of the marking pheromone of the males (Pamilo et al., 1997; Bertsch, $1997 \mathrm{a}, \mathrm{b})$. The second characteristic is known to be speciesspecific. In Scandinavia, the labial gland secretions of males were used to identify two forms of Bombus lapponicus (Bergström \& Svensson, 1973), which were later classified as distinct species, Bombus lapponicus (blonde form) and Bombus scandinavicus (dark form) (Svensson \& Bergström, 1977). Svensson (1979, 1980) later synonymised Bombus scandinavicus with Bombus monticola.

The first analysis of the chemical composition of the labial gland secretion of $B$. lucorum males was reported by Calam (1969). He identified the main component (ethyl 9-tetradecenoate) and several of the minor components. $B$ lucorum occurring in Sweden was studied extensively by Kullenberg et al. (1970) and Bergström et al. (1973). The labial gland secretions of individuals of a wide variety of colour, ranging from light yellow to dark, from the island Öland were analysed. While that of the blonde form contained mainly ethyl (Z)-9-tetradecenoate, the dark form produced mainly ethyl dode- canoate (Kullenberg et al., 1970). The "dark" form was later transferred to B. cryptarum (Rasmont et al., 1986; Bertsch, $1997 \mathrm{a}, \mathrm{b})$.

Bumblebees belonging to the " $B$. lucorum species group" occur in Czech Republic (Tkalcu, 1974, 1999), but the chemical composition of the males' labial gland secretion is unknown. The purpose of this study was to make a detailed analysis of the labial secretions of specimens collected in different localities in the Czech Republic, to determine the species on the basis of both morphological and chemical traits and to compare our results with the data in the literature.

\section{MATERIAL AND METHODS}

Insects. Males (26 individuals) of the bumblebee species Bombus lucorum were collected in the summers of 1994-1999 at seven different localities in the Czech Republic (both in Bohemia and Moravia, Table 1). Some of the males came from colonies that were established artificially using mated females from the previousyear. The insect material is deposited in the collection of one of the authors (O.H.).

For the chemical analyses, living insects were transported to the laboratory and then kept in a freezer until the labial glands were dissected. The glands were extracted with hexane $(50 \mu 1$ per gland). After 15 minutes of shaking and $2 \mathrm{~h}$ standing in the refrigerator, the hexane extract was filtered and stored in a freezer before analysis. Each sample was analysed separately.

Gas chromatography. The extracts were analysed using a gas chromatograph with a splitless injector $\left(200^{\circ} \mathrm{C}\right)$ and a mass detector (Fisons MD 800). A BPX5 column (5\% phenyl methyl silicone; $30 \mathrm{~m} \times 0.22 \mathrm{~mm}$, film thickness $0.25 \mu \mathrm{m}$ ) and helium (flow $0.55 \mathrm{ml} / \mathrm{min}$ at $50^{\circ} \mathrm{C}$ ) were used for the separations. The temperature program started at $70^{\circ} \mathrm{C}$ ( 2 minutes delay) after which the temperature was increased to $140^{\circ} \mathrm{C}$ at a rate of $40^{\circ} \mathrm{C} / \mathrm{min}$, then to $240^{\circ} \mathrm{C}$ at a rate of $2^{\circ} \mathrm{C} / \mathrm{min}$, and finally to $300^{\circ} \mathrm{C}$ at a rate of $5^{\circ} \mathrm{C} / \mathrm{min}$. Compounds were identified by comparing their mass spectra with those in the National Institute of Standards and Technology Library (NIST, U.S.A.) and by co-chromatography with synthetic or commercially available standards.

The double bond positions were determined from mass spectra of dimethyl disulphide (DMDS) adducts of unsaturated components. The configurations of the double bonds in the following compounds were determined (after their chroma- 
tographic separation) from the retention times and cochromatography with the corresponding $E$ - and Z-standards (isothermally $160^{\circ} \mathrm{C}$ for ethyl 9-hexadecenoate, $200^{\circ} \mathrm{C}$ for ethyl 9-octadecenoate, $170^{\circ} \mathrm{C}$ for 9-hexadecenol and 11-octadecenol on a DB-1 column ( methyl silicone $-30 \mathrm{~m} \times 0.25 \mathrm{~mm}$, film thickness $0.25 \mu \mathrm{m}$ ); hydrogen as carrier gas, flow $1.2 \mathrm{ml} / \mathrm{min}$; Hewlett-Packard 5890A). The double bond configurations in unsaturated hydrocarbons were determined from infrared spectra measured on a Bruker IFS- 88 instrument in a $\mathrm{KBr}$ micropellet (1.5 mm diameter). The elution order of the isomers of unsaturated ethyl esters was determined from the analogy with chromatographic properties (equivalent chain length values) of fatty acids methyl esters according to the data in the literature (Christie, 1988; Stránský et al., 1997). The identity of $(Z, Z)-9,12$-octadecadienol and $(Z, Z, Z)-9,12,15$-octadecatrienol was verified by co-chromatography with commercial standards, on two different columns, and by their mass spectra

Preparative column chromatography and derivatisation. A hexane extract of one selected gland $(50 \mu 1)$ was chromatographed on silica gel Merck $60(0.040-0.063 \mathrm{~mm} ; 290 \mathrm{mg})$ in a Pasteur pipette. The elution of the sample started with pentane, followed by hexane/ether mixtures $(1 \%-40 \%$ of ether). Fractions were checked by GC-MS and those containing unsaturated compounds were derivatised with DMDS according to the procedure published by Attygalle et al. (1993). The products were analysed by GC-MS using the same temperature program as for the original extracts.

Evaluation of GC data. The analytical results were evaluated by multivariate data analyses PCA (principal components analysis) and PLS-DA (projections to latent structuresdiscriminant analysis) (Wold et al., 1989), which are included in CODEX $^{\circledR}$ (SumLT System AB, Sweden). The GC-data were pretreated as in earlier investigations (Sjödin et al., 1989; Valterová et al., 1995). The normalised data were logarithmically transformed and represented as a matrix X. Each variable was scaled to unit variance (autoscaling).

In PLS-DA, the Y matrix was made up as a single dummy variable, each male being given a value -1 or 1 depending on the group of males to which it belonged. The significance, i.e. the number of significant components, was determined by crossvalidation. The importance of the constituents in differentiating between the two groups of bumblebees was determined from the loading plots (Wold et al., 1989).

\section{RESULTS}

All the males belonged to the "blonde" form, in particular the medium blonde form as figured in Bergström et al. (1973, Plate I, Figs $2-4$ ). The material was slightly variable. The variability in the colouration of the Czech males corresponds to that cited for $B$. lucorum males by Rasmont et al. (1986).

The composition of the labial gland secretion of $B$. lucorum males is summarised in Table 2. The positions of the double bonds are specified in Table 2 except for minor components (content $<0.1 \%$ ) and polyunsaturated compounds where the DMDS adducts were not found. The configurations of the double bonds, as determined either from the co-chromatography with standards or from infrared spectra (absence of the band 965 $\mathrm{cm}^{-1}$, which is intensive and typical for $E$-isomers), were $Z$ in all cases.

In all the Czech samples, ethyl (Z)-9-tetradecenoate dominated (mean value $52.9 \%$ ) but was present in variable quantities. Present in the medium-abundant category $(3-10 \%)$ were ethyl dodecanoate $(5.9 \%)$, hexadecanol $(3.6 \%)$, ethyl 9-hexadecenoate $(3.6 \%)$, and tricosane $(5.4 \%)$. In some samples, relatively high proportions of tetradecenoic acid $(2.5 \%)$ and hexadecyl tetradecenoate $(5.3 \%)$ were identified. In the minor category $(1-2 \%)$ were ethyl tetradecanoate, 7-hexadecenal, 11-octadecenol, ethyl 9-octadecenoate, 9-pentacosene, pentacosane, and tetradecenyl octadecatrienoate. With the exception of 7-hexadecenal, 11-octadecenol and the wax-type esters, all of the above mentioned compounds were identified in the labial gland secretion of the Scandinavian "blonde form" (Bergström et al., 1973). Many trace components (less than 1\%) not reported in the literature for B. lucorum, were detected in the Czech samples.

Traces of the sesquiterpenic alcohols farnesol and 2,3-dihydrofarnesol (below 0.1\%) were detected in Czech bumblebees. The Scandinavian blonde form did not contain any isoprenoids (Bergström et al., 1973). We also detected several compounds with larger molecules than pentacosane. The majority were present in trace amounts, but substantial quantities of 9-heptacosene and wax-type esters were present, especially in some of the samples. It is possible that these compounds were not analysable by the older techniques, which may account for why they were not recorded previously.

The principal components analysis (PCA) showed a slight tendency for the data to separate into two groups, one containing the males collected in 1997 and one containing all the other males. However, cross-validation revealed no significant components $(\mathrm{CSV} / \mathrm{SD}(1)=0.97)$. A PCA, in which hydrocar-

Table 1. Data on where and when the Bombus lucorum males were collected.

\begin{tabular}{|c|c|c|c|c|c|c|}
\hline $\begin{array}{c}\text { Number of } \\
\text { samples }\end{array}$ & $\begin{array}{c}\text { Year of col- } \\
\text { lection }\end{array}$ & $\begin{array}{c}\text { Region in the Czech } \\
\text { Republic }\end{array}$ & Locality & Type & $\begin{array}{c}\text { Elevation } \\
(\mathrm{m})\end{array}$ & $\begin{array}{l}\text { Map field } \\
\text { code }\end{array}$ \\
\hline 3 & $1994^{\mathrm{a}}$ & Central Moravia & Prostějov & edge of flooded forest & 220 & 6568 \\
\hline 1 & 1995 & Central Bohemia & Žebrák & field margin & 340 & 6149 \\
\hline 1 & 1995 & České středohoří Mountains & Oblík & steppe & 510 & 5548 \\
\hline 1 & 1995 & Central Bohemia & Praha-Dejvice & garden & 220 & 5852 \\
\hline 1 & 1995 & Krkonoše Mountains & Horní Albeřice & wet mountain meadow & 750 & 5361 \\
\hline 6 & 1997 & Central Bohemia & Praha-Dejvice & garden & 220 & 5852 \\
\hline 3 & 1998 & South Moravia & Pálava & steppe & 420 & 7165 \\
\hline 4 & 1998 & Krkonoše Mountains & Horní Albeřice & wet mountain meadow & 750 & 5361 \\
\hline 2 & 1998 & České stř̌edohoří Mountains & Oblík & steppe & 510 & 5548 \\
\hline 4 & $1999^{\mathrm{b}}$ & South Moravia & Brno-Královo Pole & garden & 235 & 6765 \\
\hline
\end{tabular}

${ }^{\mathrm{a}}$ Males from a colony artificially established using a mated queen from the previous year

${ }^{b}$ Males from one nest 
bons and fatty acids were excluded, resulted in a model with one component on the limit of significance (CSV/SD $=0.94$, variance explained $(1)=22 \%$ ) that showed the same pattern of groups. Hydrocarbons present in the gland extracts are not considered to be the active components (Bergman, 1997). Free fatty acids are most probably precursors of the components in the secretion (Bergman, personal communication). Therefore, hydrocarbons and free fatty acids were excluded from the following analysis.

A PLS-DA (for males $1997 \mathrm{Y}=-1$ and for the other males $\mathrm{Y}$ $=1)$ resulted in one significant component $(\mathrm{CSV} / \mathrm{SD}=0.69$, variance explained in $\mathrm{X}=21 \%$, variance explained in $\mathrm{Y}=$ $58 \%$ ). The loading plot showed that the most important constituents separating the males collected in 1997 from the rest were the wax-type esters. They produced higher quantities of hexadecyl dodecanoate $(0.4-1.2 \%)$, octadecadienyl dodecanoate $(0.2-0.7 \%)$, hexadecyl tetradecenoate $(4.5-22.5 \%)$, and tetradecenyl octadecatrienoate $(2.4-7.7 \%)$. The function of these "heavy" molecules in the secretion of some males remains unknown. No grouping based on origin was observed.

\section{DISCUSSION}

Although the males collected in 1997 differed from the rest of the males, the order of difference is very small compared to that between the Scandinavian dark and blonde forms described by Bergström et al. (1973). Therefore, B. lucorum in the Czech Republic are all chemically similar and more similar to the Scandinavian blonde form than to the dark form (Bergström et al., 1973). All the major components we found were also found by Bergström in the blonde form. Compounds reported only from the dark form (ethyl decanoate, ethyl octadecadienoate, geranylgeraniol, and geranylgeranyl acetate) were not found in the Czech males. The literature on "lucorum species group" and our results point to the conclusion that the Czech specimens belonged to $B$. (s.str.) lucorum and not to B. cryptarum or $B$. magnus (Bertsch, 1997a). Differences between individuals were most probably due to differences in age or physiological conditions rather than their origin.

The composition of the labial gland secretion of B. cryptarum (Bertsch, 1997a) corresponds to that of the "dark form" of $B$.

TABLE 2. Composition of the labial gland secretion of $B$. lucorum males.

\begin{tabular}{|c|c|c|c|c|}
\hline \multirow{2}{*}{ Compound } & \multirow{2}{*}{ Double bond position ${ }^{a}$} & \multicolumn{3}{|c|}{ Relative proportions $(\% ; \mathrm{N}=26)$} \\
\hline & & Mean & Range & S.D. \\
\hline \multicolumn{5}{|l|}{ Aliphatic Esters } \\
\hline Methyl tetradecenoate & n.d. & 0.032 & $0-0.3$ & 0.068 \\
\hline Ethyl dodecenoate & n.d. & 0.032 & $0-0.2$ & 0.083 \\
\hline Ethyl dodecanoate ${ }^{\mathrm{b}}$ & - & 5.921 & $1.6-16.2$ & 3.149 \\
\hline Ethyl tetradecenoate & 7 & 0.282 & $0-1.0$ & 0.272 \\
\hline Ethyl tetradecenoate ${ }^{b}$ & 9 & 52.880 & $15.1-87.4$ & 20.879 \\
\hline Ethyl tetradecanoate ${ }^{\mathrm{b}}$ & - & 1.834 & $0.2-5.3$ & 1.464 \\
\hline Ethyl hexadecenoate & 7 & 0.245 & $0.001-1.4$ & 0.261 \\
\hline Ethyl hexadecenoate ${ }^{b}$ & 9 & 3.575 & $1.0-6.6$ & 1.380 \\
\hline Ethyl hexadecenoate & 11 & 0.227 & $0.04-0.6$ & 0.174 \\
\hline Ethyl hexadecanoate & - & 0.042 & $0-0.3$ & 0.063 \\
\hline Ethyl octadecenoate & 9 & 1.821 & $0.3-4.3$ & 0.990 \\
\hline Ethyl octadecatrienoate ${ }^{\mathrm{b}}$ & n.d. & 0.209 & $0-1.8$ & 0.376 \\
\hline Ethyl octadecanoate & - & 0.083 & $0-0.3$ & 0.067 \\
\hline Ethyl icosenoate & n.d. & 0.022 & $0-0.2$ & 0.034 \\
\hline Dodecyl acetate & - & 0.022 & $0-0.5$ & 0.096 \\
\hline Tetradecadienyl acetate & n.d. & 0.127 & $0-0.6$ & 0.125 \\
\hline Hexadecyl acetate & - & 0.526 & $0-4.6$ & 1.005 \\
\hline Octadecadienyl acetate & $9, ?$ & 0.048 & $0-0.4$ & 0.082 \\
\hline Icosenyl acetate & n.d. & 0.026 & $0-0.1$ & 0.043 \\
\hline Icosyl acetate & - & 0.043 & $0-0.4$ & 0.079 \\
\hline Docosenyl acetate & n.d. & 0.041 & $0-0.1$ & 0.039 \\
\hline Hexadecyl dodecanoate & - & 0.343 & $0.02-0.8$ & 0.332 \\
\hline Octadecadienyl dodecanoate & n.d. & 0.139 & $0.001-0.7$ & 0.182 \\
\hline Hexadecyl tetradecenoate & n.d. & 5.295 & $0.2-22.5$ & 5.814 \\
\hline Tetradecenyl octadecatrienoate & n.d. & 1.842 & $0.07-7.7$ & 2.302 \\
\hline \multicolumn{5}{|l|}{ Aliphatic Aldehydes } \\
\hline Tetradecanal & - & 0.013 & $0-0.3$ & 0.028 \\
\hline Hexadecenal & 7 & 1.569 & $0.001-5.7$ & 1.656 \\
\hline Hexadecanal & - & 0.260 & $0-0.9$ & 0.275 \\
\hline Octadecenal & 9 & 0.524 & $0-1.8$ & 0.606 \\
\hline \multicolumn{5}{|l|}{ Aliphatic Alcohols } \\
\hline Hexadecenol & 9 & 0.231 & $0-5.8$ & 1.116 \\
\hline Hexadecanol $^{b}$ & - & 3.591 & $0-14.8$ & 4.143 \\
\hline Octadecadienol & 9,12 & 0.829 & $0-5.0$ & 1.453 \\
\hline Octadecatrienol & $9,12,15$ & 1.254 & $0-6.5$ & 1.795 \\
\hline Octadecenol & 11 & 0.110 & $0-1.7$ & 0.330 \\
\hline \multicolumn{5}{|l|}{ Isoprenoids } \\
\hline Farnesol & - & 0.105 & $0-0.4$ & 0.097 \\
\hline 2,3-Dihydrofarnesol & - & 0.054 & $0-0.2$ & 0.061 \\
\hline Dihydrofarnesyl tetradecenoate & n.d. & 0.152 & $0-1.2$ & 0.241 \\
\hline
\end{tabular}


Fatty Acids

Dodecanoic acid

Tetradecenoic acid

0.278

2.544

0.360

Henicosane $^{b}$

Tricosene ${ }^{b}$

Tricosene

Tricosane ${ }^{b}$

Tetracosene

Tetracosane

Pentacosene $^{b}$

Pentacosene

Pentacosane $^{b}$

Hexacosene

Hexacosene

Heptacosene

Heptacosene

Heptacosane

Octacosene

Nonacosene

Nonacosene

Nonacosane

Hentriacontene

Tritriacontatriene

Tetratriacontadiene

${ }^{a} Z$-configuration in all cases as determined either by ${ }^{b}$ reported by Bergström et al. (1973) in the blonde form (semiquantitative data), n.d. $=$ not determined because of the low content of
the component

lucorum (Bergström et al., 1973). The components of the marking pheromone of $B$. magnus have not been described in detail. Bertsch (1997a) mentions the two main components (9,12-octadecadienol and 9,12,15-octadecatrienol) of the secretion collected from artificially reared B. magnus, that originated from Scotland. Czech $B$. lucorum males produced these two compounds, too, but both in small amounts $(0.8 \%$ and $1.3 \%$, respectively).

B. lucorum is the most common species of the "lucorum species group" in the localities where we collected our specimens This agrees with the data in the literature. $B$. cryptarum and $B$. magnus are rare in the Czech Republic as we have not found any individuals that belong to these species. Although the males we collected were slightly variable in colour, they all belonged to one "chemical form", similar to the Scandinavian blonde form of this species or more simply B. lucorum. It is apparent from our results and the literature that the composition of the labial gland secretion can be used to determine species in cases where morphological traits fail or are difficult to use.

ACKNOWLEDGEMENTS. This work was financially supported by the Grant Agency of the Czech Republic (grant No. 203/98/0453) and Ministry of Education of the Czech Republic (COST project No. 828.20), which are gratefully acknowledged. The authors also wish to thank Pavel Krieg (Apiculture Research Institute, Prostějov, Czech Republic) and Vladimír Ptáček (Masaryk University, Brno, Czech Republic) for providing insects from artificially established colonies, Kristina Sjödin (Mid Sweden University, Sundsvall, Sweden) for her comments on the statistical analysis and Jan Žd'árek (Institute of Organic Chemistry and Biochemistry, Prague, Czech Republic) for his valuable comments on this manuscript.

\section{REFERENCES}

Attygalle A.B., Jham G.N. \& Menwwald J. 1993: Determination of double-bond position in some unsaturated terpenes and other branched compounds by alkylthiolation. Anal. Chem. 65: 2528-2533.

Bergman P. 1997: Chemical Communication in Bumblebee Premating Behaviour. Ph.D. Thesis, Göteborg University, 30 pp. +6 Annexes.

Bergström G., Kullenberg B. \& Ställberg-Stenhagen S. 1973: Studies on natural odoriferous compounds: VII. Recognition of two forms of Bombus lucorum L. (Hymenoptera, Apidae) by analysis of the volatile marking secretion from individual males. Chem. Scr. 4: 174-182.

Bergström G. \& Svensson B.G. 1973: Studies on natural odoriferous compounds: VIII. Characteristic marking secretions of the forms lapponicus and scandinavicus of Bombus lapponicus Fabr. (Hymenoptera, Apidae). Chem. Scr. 4: 231-238.

BerTSCH A. 1997a: Abgrenzung der Hummel-Arten Bombus cryptarum und B. lucorum mittels männlicher LabialdrüsenSekrete und morphologischer Merkmale (Hymenoptera, Apidae). Entomol. Gener. 22: 129-145.

BerTsCh A. 1997b: Wieviele Arten der Untergattung Terrestribombus (Hymenoptera, Apidae) gibt es in Nordhessen; die Abgrenzung von Bombus cryptarum und B. lucorum mittels männlicher Labialdrüsen-Sekrete und morphologischer Merkmale. Marburger Entomol. Publ. 2: 1-28.

CALAM D.H. 1969: Species and sex-specific compounds from the heads of male bumblebees (Bombus spp.). Nature (London) 221: 856-857.

Christie W.W. 1988: Equivalent chain length of methyl ester derivatives of fatty acids on gas chromatography: A reappraisal. J. Chromatogr. 447: 305-314.

KRÜGER E. 1954: Phaenoanalytische Studien an einigen Arten der Untergattung Terrestribombus O. Vogt (Hymenoptera, Bombidae). II. Tijdschr. Entomol. 97: 263-298.

Kullenberg B., Bergström G. \& Ställberg-Stenhagen S. 1970: Volatile components of the cephalic marking secretion of male bumble bees. Acta Chem. Scand. 24: 1481-1483. 
LøKen A. 1973: Studies on Scandinavian Bumble Bees (Hymenoptera, Apidae). Norsk Entomol. Tidsskr. 20: 1-218.

Pamilo P., Tengö J., Rasmont P., Pirhonen K., Pekkarinen A. \& KaARnama E. 1997: Pheromonal and enzyme genetic characteristics of the Bombus lucorum species complex in northern Europe. Entomol. Fenn. 7: 187-194.

RASMONT P. 1984: Les bourdons du genre Bombus Latreille sensu stricto en Europe Occidentale et Centrale (Hymenoptera, Apidae). Spixiana 7: 135-160.

Rasmont P., Scholl A., de Jonghe R., Obrecht E. \& Adamski A. 1986: Identité et variabilité des mâles de bourdons du genre Bombus Latreille sensu stricto en Europe occidentale et centrale (Hymenoptera, Apidae, Bombinae). Rev. Suisse Zool. 93: $661-682$.

SCHOLl A. \& OBRECHT E. 1983: Enzymelektrophoretische Untersuchungen zur Artabgrenzung im Bombus lucorum-Komplex (Apidae, Bombini). Apidologie 14: 65-78.

SCHOLl A., THORP R.W. \& OBRECHT E. 1992: The genetic relationship between Bombus franklini (Frison) and other taxa of the subgenus Bombus s.str. (Hymenoptera: Apidae). Pan-Pac. Entomol. 68: 46-51.

Suödin K., Schroeder L.M., Emmann H.H., Norin T. \& Wold S 1989: Attack rates of scolytids and composition of volatile wood constituents in healthy and mechanically weakened pine trees. Scand. J. For. Res. 4: 379-391.

STRÁNSKÝ K., JURSíK T. \& VÍteK A. 1997: Standard equivalent chain length values of monoenic and polyenic (methylene interrupted) fatty acids. J. High Resolut. Chromatogr. 20: $143-158$.

Svensson B.G. 1979: Pyrobombus lapponicus auct. in Europe recognized as two species: P. lapponicus (Fabricius, 1793) and P. monticola (Smith, 1849) (Hymenoptera, Apoidea, Bombinae). Entomol. Scand. 10: 275-296.
SVENSSON B.G. 1980: Species-isolating mechanisms in male bumble bees (Hymenoptera, Apidae). Acta Univ. Uppsal. 549: $1-42$.

Svensson B.G. \& BergströM G. 1977: Volatile marking secretions from the labial gland of North European Pyrobombus D. T. males (Hymenoptera, Apidae). Insectes Soc. 24: 213-224.

Tkalcof B. 1974: Bemerkenswerte Bienenfunde in der Tschechoslowakei (Hymenoptera, Apoidea). Acta Entomol. Bohemoslov. 71: 205-208.

TKalco B. 1999. Two species of bumblebees new for the Czech Republic (Hymenoptera: Apoidea). Sbor. Přrir. Klubu v Uh. Hradišti 4: 121-123.

Valterová I., SJödin K., VRKoč J. \& Norin T. 1995: Contents and enantiomeric compositions of monoterpene hydrocarbons in xylem of oleoresins from four Pinus species growing in Cuba. Comparison of trees unattacked and attacked by Dioryctria horneana. Biochem. Syst. Ecol. 23: 1-15.

WARNCKE K. 1981: Die Bienen des Klagenfurter Beckens (Hymenoptera, Apidae). Carinthia II 171/91: 275-348.

WARNCKE K. 1986: Die Wildbienen Mitteleuropas, ihre gültige Namen und ihre Verbreitung (Insecta: Hymenoptera). Entomofauna 3: 1-128.

Williams P.H. 1991: The bumble bees of the Kashmir Himalaya (Hymenoptera: Apidae, Bombini). Bull. Br. Mus. Nat. Hist. (Entomol.) 60: 1-204.

Wold S., Albano C., Dunn III W.J., Esbensen K., Geladi P., Hellberg S., Johansson E., Lindberg W., Suöström M., SkAgerberg B., WiKström C. \& Öhman J. 1989: Multivariate data analysis: Converting chemical data tables to plots. Intell. Instrum. Comput. 7: 197-216.

Received June 26, 2000; revised September 8,2000; accepted October 16, 2000 